\title{
Selection of SSR markers for population studies in Eucalyptus globulus seed orchards
}

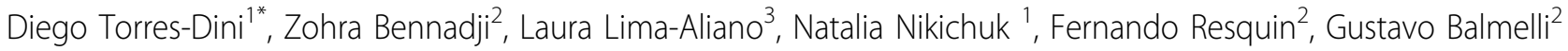 \\ From IUFRO Tree Biotechnology Conference 2011: From Genomes to Integration and Delivery \\ Arraial d'Ajuda, Bahia, Brazil. 26 June - 2 July 2011
}

\begin{abstract}
Background
Eucalyptus globulus is a widely planted species in temperate regions of the world for pulpwood production. Its good characteristics for kraft pulping in addition to a broad adaptability to different site conditions have led this species to be employed in commercial plantations and to be included in breeding programs [1]. Uruguay has approximately 300.000 hectares forested with E. globulus being the most cultivated species in the country and representing $45 \%$ of the total forested area. The main objectives of many Uruguayan breeding programs for E. globulus are the increase of volume per hectare, basic density and pulp yield. The strategies for genetic improvement used in many breeding programs in Uruguay require seed multiplication in seed orchards to obtain genetic gain [2].

In long-term breeding programs, the strict selection of reproductive populations restricts the number of genotypes involved in the final orchard, thus reducing genetic diversity and increasing the risk of depression through inbreeding in the following generations. The use of SSRs (simple sequence repeat) markers as selecting strategies of seed orchards in other species such as Eucalyptus dunni, has proved to be an excellent tool to reduce inbreeding $[3,4]$. The transferability of SSR markers across Eucalyptus species has been widely studied [5-8]. The aim of this work was to select highly polymorphic SSR markers of E. globulus to assist breeding programs.
\end{abstract}

\section{Methodology}

Eighteen E. globulus samples were collected from the breeding program of the National Agricultural Research Institute of Uruguay .DNA was extracted with CTAB

\footnotetext{
* Correspondence: dtorres@tb.inia.org.uy

${ }^{1}$ Forest Biotechnology Laboratory, INIA Tacaurembo, Uruguay

Full list of author information is available at the end of the article
}

2X buffer [9]. Eight SSR markers, previously reported for E. grandis and E. urophylla were used: EMBRA 8, EMBRA 11, EMBRA 18, EMBRA 32, EMBRA 47, EMBRA 51, EMBRA 58 and EMBRA $155[6,7]$ The annealing temperature was specifically adjusted for E. globulus using a temperature gradient of $52^{\circ} \mathrm{C}-56^{\circ} \mathrm{C}$. The other reaction parameters did not differ from those previously reported. The results were visualized in polyacrilamyde gels $8 \%$ under denaturing conditions at 80 W constant power over $3 \mathrm{~h} 30 \mathrm{~min}$ and were stained with silver nitrate. The estimation of the molecular weight of the alleles was made by comparison with a ladder. The matrix information was analyzed with the software Identity v 1.0 [10] and the following parameters were calculated: alleles number per loci, expected heterozygosity $(\mathrm{He})$, observed heterozygosity (Ho), identity probability (Pi) and paternity exclusion probability $(\mathrm{Pe})$.

\section{Results and conclusion}

From the eight tested markers, EMBRA 8, EMBRA 18 and EMBRA 13 did not amplify at any of the tested temperatures. EMBRA 11 and EMBRA 47 showed good amplification at $52^{\circ} \mathrm{C}$ of annealing. The rest of the primers worked optimally in the conditions previously described for E. grandis and E. urophylla[7]. The five SSRs markers amplified a total of 42 alleles. With a maximum of 14 alleles for EMBRA 11, 9 alleles for the markers EMBRA 47 and EMBRA 58 and 5 alleles for the markers EMBRA 51 and EMBRA 155. The range of heterozygosity expected for all the loci ranged from 0.64 to 0.88 . However, the observed heterozygosity showed values of 0.1 to 0.9 . With this information the probability of identity (IP) was $17 \times 10^{-5}$ and the paternity exclusion probability was 0.99 . The considerable number of SSR markers currently published [6-8] confirm how necessary the availability of these tools is to carry out precise population analyses. The five identified markers 
turned out to be promising candidates to be used in $E$. globulus seed orchards population studies.

\section{Author details}

${ }^{1}$ Forest Biotechnology Laboratory, INIA Tacaurembo, Uruguay. ${ }^{2}$ Fosrestry Breeding Program, INIA Tacuarembo, Uruguay. ${ }^{3}$ Uruguay.University of the Republic, Montevideo Uruguay.

Published: 13 September 2011

\section{References}

1. Freeman J, Whittock S, Potts B, Vaillancourt R: QTL influencing growth and wood properties in Eucalyptus globulus. Tree Genetics \& Genomes 2009, 5:713-722.

2. Balmelli G, Kubota M: Estimación de parámetros genéticos en la segunda generación de Eucalyptus grandis y su utilización para el manejo de la población multipropósito. Serie Aftercare Forestal INIA-JICA 2002, 41-11.

3. Marcucci-Poltri S, Zelener N, Traverso J, Gelid P, Hopp E: Selection of a seed orchard of Eucalyptus dunnii based on genetic diversity criteria calculated using molecular markers. Tree physiology 2003, 23:625.

4. Zelener N, Marcucci-Poltri S, Bartoloni N, López C, Hopp E: Selection strategy for a seedling seed orchard design based on trait selection index and genomic analysis by molecular markers: a case study for Eucalyptus dunnii. Tree Physiology 2005, 25:1457-1467.

5. Sansaloni C: Desenvolvimento, caracterizacao e mapeamento de microssatelites tetra y pentanucleotidos em Eucalyptus ssp. Brazilia: Universidade de Brazilia; 2008.

6. Brondani RPV, Brondani C, Tarchini R, Grattapaglia D: Development, characterization and mapping of microsatellite markers in Eucalyptus grandis and E. urophylla. Theor Appl Genet 1998, 5:816-827.

7. Brondani RPV, Williams ER, Brondani C, Grattapaglia D: A microsatellitebased consensus linkage map for species of Eucalyptus and a novel set of 230 microsatellite markers for the genus. BMC Plant Biology 2006, 6:20-36.

8. Faria D, Mamani E, Pappas G, Grattapaglia D: Genotyping systems for Eucalyptus based on tetra-, penta-,and hexanucleotide repeat EST microsatellites and their use for individual fingerprinting and assignment tests. Tree Genetics \& Genomes 2011, 7:63-77.

9. Ferreira M, Grattapaglia D: Introducao ao uso de marcadores RAPD e RFLP em análise genética. EMBRAPA.CENARAGEN 1995, 1-220.

10. Wagner H, Sefc K: Identity 1.0. Centre for Applied Genetics. University of Agricultural Sciences, Vienna; 1999, Availableathttp://www.boku.ac.at/zag/ forsch/identity.htm.

doi:10.1186/1753-6561-5-S7-P59

Cite this article as: Torres-Dini et al: Selection of SSR markers for population studies in Eucalyptus globulus seed orchards. BMC Proceedings 2011 5(Suppl 7):P59.

\section{Submit your next manuscript to BioMed Central and take full advantage of:}

- Convenient online submission

- Thorough peer review

- No space constraints or color figure charges

- Immediate publication on acceptance

- Inclusion in PubMed, CAS, Scopus and Google Scholar

- Research which is freely available for redistribution

Submit your manuscript at www.biomedcentral.com/submit
Biomed Central 